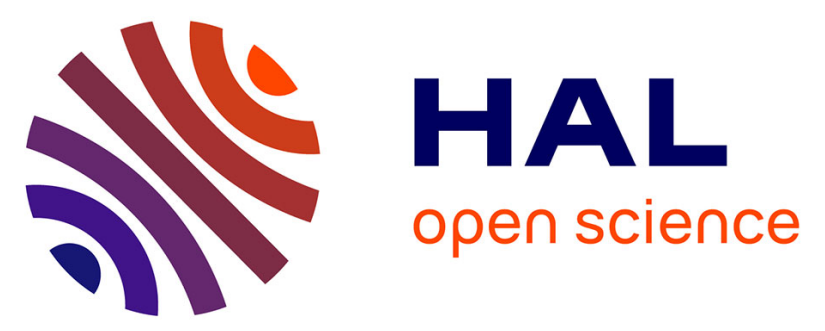

\title{
Ancient polycyclic aromatic hydrocarbons in modern soils: 13C, 14C and biomarker evidence
}

Eric Lichtfouse, Hélène Budzinski, Philippe Garrigues, Timothy Eglinton

\section{To cite this version:}

Eric Lichtfouse, Hélène Budzinski, Philippe Garrigues, Timothy Eglinton. Ancient polycyclic aromatic hydrocarbons in modern soils: 13C, 14C and biomarker evidence. Organic Geochemistry, 1997, 26 (5/6), pp.353-359. 10.1016/S0146-6380(97)00009-0 . hal-00193132

\section{HAL Id: hal-00193132 https://hal.science/hal-00193132}

Submitted on 30 Nov 2007

HAL is a multi-disciplinary open access archive for the deposit and dissemination of scientific research documents, whether they are published or not. The documents may come from teaching and research institutions in France or abroad, or from public or private research centers.
L'archive ouverte pluridisciplinaire HAL, est destinée au dépôt et à la diffusion de documents scientifiques de niveau recherche, publiés ou non, émanant des établissements d'enseignement et de recherche français ou étrangers, des laboratoires publics ou privés. 
Organic Geochemistry 26, 353-359, 1997.

doi:10.1016/S0146-6380(97)00009-0

Correspondence: Dr. Eric Lichtfouse, INRA-CMSE-PME, 17, rue Sully, 21000 Dijon, France

Eric.Lichtfouse@dijon.inra.fr

\title{
Ancient polycyclic aromatic hydrocarbons in modern soils : ${ }^{13} \mathrm{C},{ }^{14} \mathrm{C}$ and biomarker evidence
}

\author{
Eric LICHTFOUSE $^{1 *}$, Hélène BUDZINSKI ${ }^{2}$, Philippe GARRIGUES ${ }^{2}$ and Thimothy I. EGLINTON ${ }^{3}$ \\ ${ }^{1}$ Laboratoire de Biogéochimie Isotopique, Université Pierre et Marie Curie, 75252 Paris Cx 05. \\ ${ }^{3}$ Laboratoire de Photophysique et Photochimie Moléculaire, UA 348 CNRS, Université de Bordeaux 1, 33405 \\ Talence Cx, France. \\ ${ }^{4}$ Marine Chemistry and Geochemistry Dept., Woods Hole Oceanographic Institution, \\ 360 Woods Hole Rd., Woods Hole, MA 02543-1543, U.S.A.
}

\begin{abstract}
Polycyclic aromatic hydrocarbons (PAHs) of soils from two maize fields were analyzed for molecular structure by gas chromatography-mass spectrometry, for ${ }^{13} \mathrm{C} /{ }^{12} \mathrm{C}$ ratios by isotope ratio mass spectrometry and for ${ }^{14} \mathrm{C}$ age by accelerator mass spectrometry. The molecular investigation indicates that the aromatic fractions are dominated by pyrolytic inputs. Calculation of molecular maturity parameters based on hopanes and PAHs gives values typical of high thermal stress such as exhibited by high rank coals and petroleums with equivalent vitrinite reflectances of $\sim 0.6-1.5 \%$. The interpretations based on molecular compositions are corroborated by isotopic data. Specifically, both the absence of ${ }^{13} \mathrm{C} /{ }^{12} \mathrm{C}$ variation of aromatic fractions during 23 years of maize cropping, and a ${ }^{14} \mathrm{C}$ age greater than 9820 years demonstrate that these substances are not derived from aromatization of modern plant material or soil biomass. Together, these results show that soil PAHs are mainly of pyrolytic origin, e.g. exogenous (airborne) contributions of fossil fuel combustion products and (old) vegetation fires, with a small contribution of uncombusted fossil fuels. This approach using molecular and isotope information represents a promising way to study the fate of ancient, reworked, fossil organic matter in modern media such as soils, sediments, plants, air and food.
\end{abstract}

Key words - carbon-13, carbon-14, soil aromatic hydrocarbons, hopane, maturity parameters, pollution.

\section{INTRODUCTION}

The occurrence of PAHs in modern media such as soils, sediments, aerosols, waters, animals and plants is of increasing environmental concern because these compounds may exhibit mutagenic and carcinogenic effects towards living organisms (Hites and Biemann, 1972, Youngblood and Blumer, 1975, Lunde and Bjorseth, 1977, Smith, 1977, Laflamme and Hites, 1978, 1979, Windsor and Hites, 1979, White, 1986, Pahlman and Pelkoner, 1987, Mac Elroy et al., 1989, Trendel et al., 1989, Lipiatou and Saliot, 1991, Simonich and Hites, 1994, Garrigues et al., 1993, 1995). The advent of high resolution analytical techniques such as capillary gas chromatography-mass spectrometry in the 70's has allowed the molecular structure of a wide array of PAHs to be elucidated. Nonetheless, with the exception of few minor PAH classes such as steroid and triterpenoid derivatives that bear enough structural information to be related to biological substances (e.g. Douglas and Mair, 1965, Laflamme and Hites, 1979, Mackenzie et al., 1982, Trendel et al., 1989, Lichtfouse and Albrecht, 1994), the sources and the transport processes leading to the presence of most PAHs in modern environments are rarely clear.

\footnotetext{
* Present address : Laboratoire Sols et Environnement, INRA/ENSAIA-INPL, 2, avenue de la Forêt de Haye, BP 172, 54505 Vandoeuvre-lès-Nancy, France.
} 
In soils, for example, PAHs may be indigenous as a result of rapid aromatization of biological compounds during humification processes (Trendel et al., 1989). They can also reflect contributions from ancient hydrocarbon sources, such as petroleum and coal residues (Tissot and Welte, 1984), provided that the soil has been initially formed by weathering of a petroleum source-rock or coal seam. Alternatively, several exogenous sources can be considered including migration of petroleum from deeper formations, fall of airborne particles, and various spills (Lunde and Bjorseth, 1977, Smith, 1977, Windsor and Hites, 1979, Tissot and Welte, 1984). Geochemists have also tried to distinguish on structural grounds petrogenic sources, that account for the direct contribution of fossil fuel, from pyrolytic or pyrogenic sources formed at relatively high temperature by incomplete combustion of fossil fuels, e.g. car exhausts, industrial emissions, and vegetation fires (Youngblood and Blumer, 1975, Wise et al.., 1988, Garrigues et al., 1995). Moreover, although a substantial amount of PAHs could be formed recently (e.g. from modern vegetation fires), the high chemical stability of their aromatic systems means that these molecules could have ancient sources such as ancient vegetation fires and fossil fuels that are somehow preserved in the modern environment.

Except for point-source pollution events such as petroleum spills, the influence of human activities on PAH assemblages is rather difficult to assess, especially when PAHs occur at very low concentrations. In that respect, it should be borne in mind that the major part of petroleum formed in deep rocks over geological periods of time has not been trapped in geological pools but has migrated, and is still slowly migrating toward modern environments through soils and sediments without any anthropogenic influence. Therefore, PAH in modern media are likely to occur as mixtures of several sources, either indigenous or exogenous, either petrogenic or pyrolytic, either ancient or modern, either anthropogenic or from natural sources. In recent investigations, we found that molecular and isotope analysis could be a means to decipher the origins of soil organic molecules (Lichtfouse and Eglinton, 1995; Lichtfouse and Budzinski, 1995; Lichtfouse et al., 1995; Lichtfouse, 1995). Here, a similar approach provides several novel insights into the provenance of PAHs in soils.

\section{EXPERIMENTAL}

Detailed crop soil characteristics are descibed elsewhere (Lichtfouse et al., 1995b, Lichtfouse and Eglinton, 1995). Soil samples were cored through the 0-30 cm ploughed horizon of two experimental cultivated fields, one at La Minière $\left(48^{\circ} 45^{\prime} \mathrm{N}\right.$, $2^{\circ} 05^{\prime} \mathrm{E}, \sim 15 \mathrm{Kms}$ from Paris), near Versailles, and the other at Boigneville $\left(48^{\circ} 20^{\prime} \mathrm{N}\right.$, $2^{\circ} 20^{\prime} \mathrm{E}, \sim 50 \mathrm{Kms}$ from Paris), Essone, France. Both sites are rural, but the La Minière field should be under higher influence of urban pollutants due to its position near Paris subburbs with a higher density of highways. Both fields have been cropped without any organic amendments. At La Minière (field A), time 0 (Table 2) refers to uncultivated soils, from the same field, previously cultivated solely with $\mathrm{C}_{3}$ plants, mainly Triticum aestivum (wheat). At Boigneville (field $\mathrm{B}$ ), time 0 refers to soils, from the same field, cultivated with Triticum aestivum. These fields were cultivated at one crop per year with the $\mathrm{C}_{4}$ plant Zea mays (maize) from 1987 to 1992 at La Minière, and from 1970 to 1993 at Boigneville, thus labelling soil organic matter at natural abundance with ${ }^{13} \mathrm{C}$ enriched carbon (Lichtfouse, 1995). 
Table 1. $\delta^{13} \mathrm{C}$ of total organic carbon (TOC) and aromatic fractions (PAH) from crop field at La Minière, France (A, 1987-92) and at Boigneville, France (B, 1970-93).

\begin{tabular}{ccccc}
\hline \multirow{2}{*}{$\begin{array}{c}\text { Time } \\
\text { (yrs) }\end{array}$} & \multicolumn{2}{c}{ TOC } & \multicolumn{2}{c}{ PAH } \\
& & & A & B \\
\hline 0 & -26.28 & -25.92 & -25.99 & -27.04 \\
4.33 & -24.96 & & -25.93 & \\
20 & & -20.74 & & -27.13 \\
23 & & -20.33 & & -27.15 \\
\hline
\end{tabular}

Dried soils were sieved to $2 \mathrm{~mm}$, finely ground and extracted ultrasonically (30 min, $\left.30^{\circ} \mathrm{C}, 3 \mathrm{X}\right)$ with $\mathrm{CHCl}_{3}-\mathrm{MeOH}(3 / 1 \mathrm{v} / \mathrm{v})$. Extracts were fractionated into neutral and acid fractions by passage through silica gel impregnated with $\mathrm{KOH}$ followed by $\mathrm{HCO}_{2} \mathrm{H}$ acidification (McCarthy and Duthie, 1962). Neutral fractions were separated into hydrocarbon-ester $\left(\mathrm{R}_{\mathrm{F}}>\sim 0.85\right)$, ketone $\left(\mathrm{R}_{\mathrm{F}} \sim 0.28-0.85\right)$, alcohol $\left(\mathrm{R}_{\mathrm{F}} \sim 0.05-\right.$ $0.28)$ and polar $\left(\mathrm{R}_{\mathrm{F}}<\sim 0.05\right)$ fractions by silica-gel thin layer chromatography $(0.25$ mm silica thickness), using $\mathrm{CH}_{2} \mathrm{Cl}_{2}$ as developer and dibenz(a,c)anthracene, friedelin and cholesterol as reference compounds. Hydrocarbon-ester fractions were fractionated into aliphatic $\left(\mathrm{R}_{\mathrm{F}}>\sim 0.89\right)$, aromatic $\left(\mathrm{R}_{\mathrm{F}} \sim 0.09-0.89\right)$ and ester fractions $\left(\mathrm{R}_{\mathrm{F}}<\sim 0.09\right)$ by silica-gel thin layer chromatography, with $n$-hexane as developer and using $n$-octacosane, 1-phenyldodecane, 2-methylphenanthrene and $\operatorname{dibenz}(\mathrm{a}, \mathrm{c})$ anthracene as reference compounds.

$\delta^{13} \mathrm{C}$ of total organic $\mathrm{C}$ and of aromatic fractions were measured by continuous flow-isotope ratio monitoring mass spectrometry (Lichtfouse et al., 1995b) and are expressed in per mil. relative to the Pee Dee Belemnite standard: $\delta^{13} \mathrm{C}=$ $\left[\left({ }^{13} \mathrm{C} /{ }^{12} \mathrm{Csample} /{ }^{13} \mathrm{C} /{ }^{12} \mathrm{Cstd}\right)-1\right] \times 10^{3}$. Aromatic and aliphatic fractions were analysed by gas chromatography-mass spectrometry (GC-MS). For aromatic fractions, conditions were : HP 5890 series II gas chromatograph, splitless injection, $30 \mathrm{~m}$ x 0.25 $\mathrm{mm}$ i.d. fused silica column, 5\%phenyl-95\%methylpolysiloxane phase $(0.25 \mu \mathrm{m}$ thickness), He flow $1 \mathrm{ml} / \mathrm{min}$, temperature : $50-290^{\circ} \mathrm{C}$ at $5^{\circ} / \mathrm{min}$ then $20 \mathrm{~min}$ isothermal, electronic impact $(70 \mathrm{eV})$, MSD 5970 mass spectrometer, $1.2 \mathrm{scans} / \mathrm{sec}$. GC-MS analyses were performed in full scan mode (50-650 uma) or single ion monitoring using the molecular ions of the studied PAHs : 178, 190, 192, 202, 228, 252, 276, 278. For aliphatic fractions, conditions were similar except : $50 \mathrm{~m}$ x $0.32 \mathrm{~mm}$ i.d. fused silica column, $100 \%$ methylpolysiloxane phase $(0.53 \mu \mathrm{m}$ thickness $)$, He flow $1.9 \mathrm{ml} / \mathrm{min}$, temperature : $50-100^{\circ} \mathrm{C}$ at $15^{\circ} / \mathrm{min}, 100-310^{\circ} \mathrm{C}$ at $3 \% \mathrm{~min}$ then $60 \mathrm{~min}$ isothermal, 50-650 uma scan mode. Identification of hydrocarbons was performed by comparison of their chromatographic and spectroscopic characteristics with literature data, pure standards and data from mature sediments and petroleums analysed in the same conditions. A $700 \mu \mathrm{g}$ sample of the aromatic fraction from the soil cultivated for 4.3 yrs were analysed for radiocarbon by accelerator mass spectrometry, as described by Lichtfouse and Eglinton (1995). This analysis gave a value of $9820 \pm 70 \mathrm{yrs}$ BP corresponding to a fraction Modern of $29.45 \%$. 
RESULTS AND DISCUSSION

The molecular structures of some PAHs and hopanes cited in this study are shown in Scheme 1

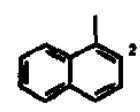

thylnephthalene

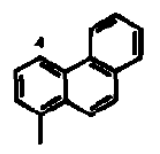

(16)

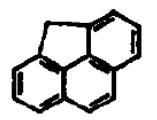

(13)

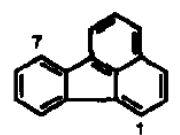

(4)

Fluoranthene

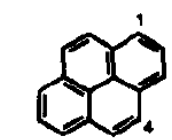

(5)
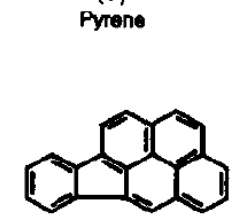

(9)

Indeno[1,2,3-c,d]pyrene

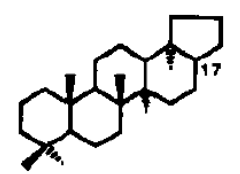

(B)
$\mathrm{Tm}$

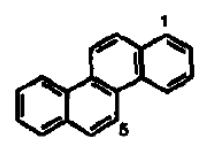

(6)

Chrysene

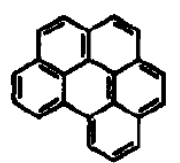

(10)

Benzolg, h, ijperylene

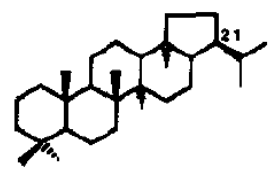

(D)

$17 \alpha, 21 \beta$-Hopane

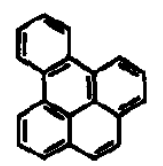

(8)

Benzo[e]pyrene

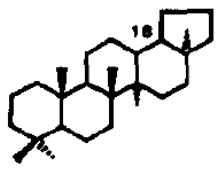

(A)

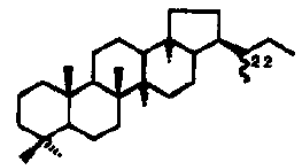

(E)

17a,21ß-Homahopanes

Scheme 1. Molecular structures of polycyclic aromatic hydrocarbons (PAHs) and hopanes

\section{Aromatic hydrocarbon distributions}

Aromatic fractions are present both at $\mathrm{La}$ Minière near Versailles and Boigneville in Essone crop fields in concentrations of $\sim 13 \mathrm{mg} / \mathrm{kg}$ of dried soil at La Minière and $\sim 7 \mathrm{mg} / \mathrm{kg}$ at Boigneville (total organic $\mathrm{C} \sim 1 \%$ ), which indicates a nonpoint source contamination rather than a massive spill. These concentrations were found to be constant with increasing time of cropping, thus suggesting a regular supply of PAHs to the soil.

The distribution of individual PAH are similar in all soil samples, and show the predominance of only a few parent PAHs of high molecular weight (Figure 1). Such a fingerprint is typical of combustion products and aerosols (Lunde and Bjorseth, 1977, Laflamme and Hites, 1978), rather than of a direct contribution of petroleum-based fuels since the latter are usually much more complex containing low molecular-weight PAH and alkylated homologues (Radke et al., 1982, 1984, Radke, 1987). 


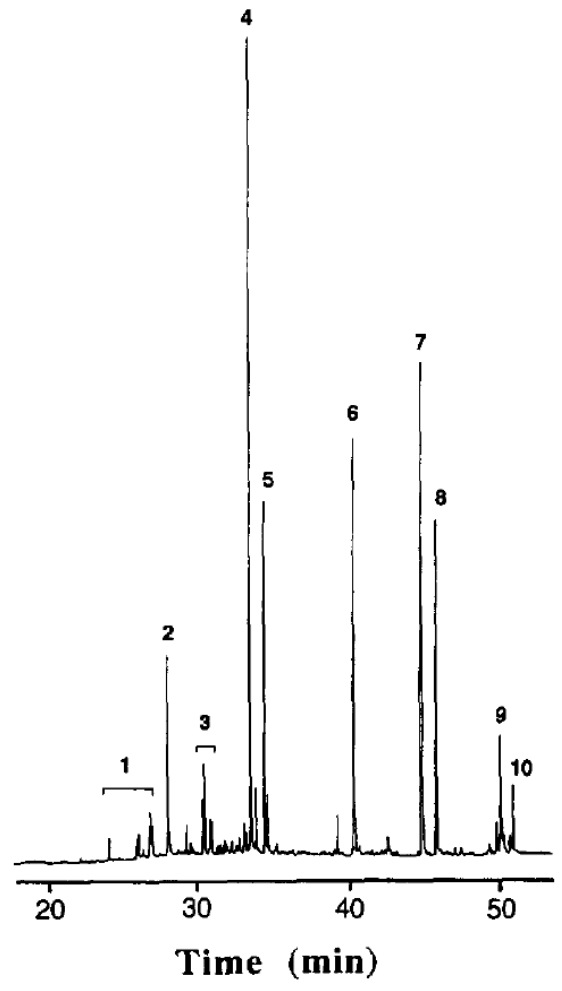

Figure 1. Aromatic hydrocarbons in crop soils. Single ion monitoring at m/z 178, 190, 192, 202, 228, 252, 276 and 278 of a typical aromatic fraction analysed by gas chromatography-mass spectrometry. $\mathbf{1}$ alkylnaphthalenes, $\mathbf{2}$ phenanthrene, $\mathbf{3}$ methylphenanthrenes, 4 fluoranthene, 5 pyrene, $\mathbf{6}$ chrysene, 7 benzofluoranthenes, $\mathbf{8}$ benzo[e]pyrene, 9 indeno[1,2,3-c,d]pyrene, 10 benzo[g,h,i]perylene.

Further evidence for a major contribution of pyrolytic products is given by 1) the high abundances of PAH with an alicyclic five-membered ring (Simoneit et al., 1990); 2) a high fluoranthene/pyrene concentration ratio of $\sim 2.3$ (Sicre et al., 1987 and refs. therein), 3) the occurrence of 4,5-methylenephenanthrene, a typical pyrolytic product commonly absent in uncombusted fossil fuels, at concentrations in the same order of magnitude as methylphenanthrene isomers (Figure 2), and 3) the occurrence of benzo[g,h,i]perylene, a compound correlated with automobile exhaust (Currie et al., 1994).

Nonetheless, the absence of anthracene derivatives, that are also usually encountered in pyrolytic products (Laflamme and Hites, 1978, Simoneit et al., 1990, Lichtfouse et al., 1994) points to a small contribution of uncombusted fossil fuels to soil PAH. Finally, we did not detect any biogenic PAH, such as plant triterpene derivatives that are formed by rapid aromatization in recent muds and sediments (Laflamme and Hites, 1979, Trendel et al., 1989). Therefore, these structural data show that crop soil PAH have mainly a pyrolytic origin with a small contribution of petrogenic compounds. The latter is clearly evidenced by the identification of trace amounts of $\mathrm{C}_{27}, \mathrm{C}_{29}, \mathrm{C}_{30}-\mathrm{C}_{32} \alpha \beta$-hopane in all soil samples (Figure 3). The $17 \alpha, 21 \beta$ configuration of these "geomarkers" is typical of thermally mature organic matter from sedimentary rocks and petroleums (Van Dorsselaer et al., 1974, Dastillung and Albrecht, 1976, Ourisson et al., 1979) but would not be expected to survive combustion processes. 


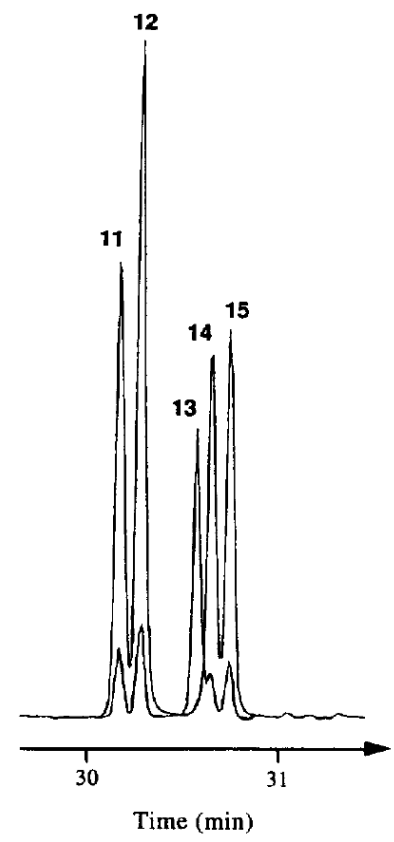

Figure 2. Alkylphenanthrene in crop soils. Reconstructed ion current at m/z 192 (upper trace) and 190 (lower trace) showing respectively methylphenanthrene isomers $(\mathbf{1 1}, \mathbf{1 2}$, 14, 15) and 4,5-methylenephenanthrene (13). 11: 3-methylphenanthrene, 12: 2-methylphenanthrene, 14: 9-methylphenanthrene, 15: 1-methylphenanthrene. The strong predominance of the 2-methyl and 3-methyl isomers is typical of mature fossil fuels. Note the high relative abundance of 4,5-methylenephenanthrene, a typical pyrolytic marker.

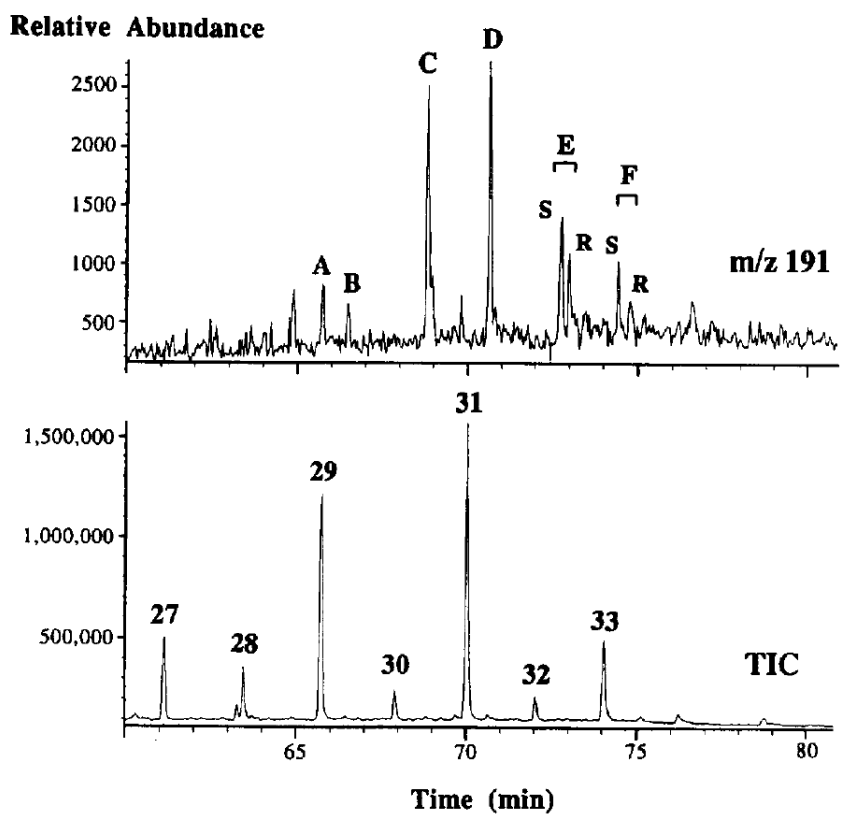

Figure 3. Trace fossil hopanes in crop soils. Total ion current (TIC) and recontructed ion current (m/z 191) of a typical alkane-alkene fraction of soil extracts. The upper trace shows hopanes homologues. The lower trace shows wax $n$-alkanes. Note the very low abundance of hopanes relative to $n$-alkanes. Numbers refer to $n$-alkane carbon number. A: $18 \alpha-22,29,30$-trisnorneohopane $\left(\mathrm{C}_{27}\right.$, Ts), B: $17 \alpha-$ 22,29,30-trisnorhopane $\left(\mathrm{C}_{27}, \mathrm{Tm}\right), \mathbf{C}: 17 \alpha, 21 \beta$-30-norhopane $\left(\mathrm{C}_{29}\right), \mathbf{D}: 17 \alpha, 21 \beta$-hopane (C30), E: D: $17 \alpha, 21 \beta$-homohopane $\left(\mathrm{C}_{31}\right), 22 \mathrm{~S}$ and $22 \mathrm{R}$ epimers, $\mathbf{F}: 17 \alpha, 21 \beta$-bishomohopane $\left(\mathrm{C}_{32}\right), 22 \mathrm{~S}$ and $22 \mathrm{R}$ epimers. All these compounds are typical of mature fossil fuels. 


\section{$P A H$ and hopane maturity parameters}

During the last 20 years, numerous parameters based on relative abundances of biomarker isomers have been designed to evaluate the transformation of organic matter in sediments and petroleums (Peters and Moldowan, 1993). In an overlooked but elegant and pioneering work, Dastillung and Albrecht (1976) demonstrated the value of hopanoid isomers to infer the presence of fossil material in surface sediments. In our study, several molecular parameters based on hopane and PAH isomers were calculated to evaluate the maturity of the non-point source contamination of soils (Table 2). All molecular parameters show values consistent with sedimentary organic matter from high maturity samples such as deeply buried sedimentary rocks, petroleums and highrank coals. Moreover, the equivalent vitrinite reflectance values shows clearly that this fossil contribution has reached the zone of petroleum generation. This contribution of ancient carbon is futher confirmed by ${ }^{14} \mathrm{C}$ analysis (see below). Alternatively, high values of $\mathrm{PAH}$ maturity parameters may result from the 'artificial' maturation of organic matter during pyrolytic processes such as vegetation fires and fuel burning.

Table 2. Molecular maturity parameters in modern crop soils. The maturity scale is roughly divided into: low (early diagenesis), medium (late diagenesis) and high (catagenesis). The equivalent vitrinite reflectance $\mathrm{R}_{0}(\%)$ is evaluated either by comparison with literature data or by calculation from maturity parameters. References : a) Seifert and Moldowan, 1978, b) Peters and Moldowan, 1993, c) Mackenzie et al., 1980, 1982, d) Radke et al., 1982, e) Radke et al., 1986, 1990, f) Radke et al., 1994, g) Garrigues et al., 1988, Lichtfouse et al., 1994. Compound identifications refer to assignments in Figures 2-3. MN : methylnaphthalene, EN : ethylnaphthalene, DMN : dimethylnaphthalene, MP : methylphenanthrene.

\begin{tabular}{|c|c|c|c|c|c|}
\hline Formula & Compound & Value & Maturity & $\mathrm{R}_{0}$ & Refs \\
\hline $\mathrm{Tm} / \mathrm{Ts}$ & A,B & 0.73 & High & & $a, b$ \\
\hline $\mathrm{C}_{31} \mathrm{~S} /(\mathrm{S}+\mathrm{R})$ & $\mathrm{E}$ & $59 \%$ & High & $>0.6$ & $\mathrm{c}$ \\
\hline $\mathrm{C}_{32} \mathrm{~S} /(\mathrm{S}+\mathrm{R})$ & $\mathrm{F}$ & $65 \%$ & High & $>0.6$ & $\mathrm{c}$ \\
\hline 2-MN/1-MN & & 2.2 & High & $1-1.5$ & $\mathrm{~d}, \mathrm{e}$ \\
\hline 2-EN/1-EN & & 1.5 & High $\quad$ & $0.6-1.2$ & $\mathrm{~d}, \mathrm{e}$ \\
\hline $\begin{array}{l}(2,6-+2,7-\mathrm{DMN}) \\
1,5-\mathrm{DMN})\end{array}$ & & 5.0 & High & 1.4 & $\mathrm{~d}, \mathrm{f}$ \\
\hline $\begin{array}{l}\text { 2-MP/1-MP } \\
(2-\mathrm{MP}+3-\mathrm{MP}) /\end{array}$ & 12,15 & 1.8 & High & $>1.2$ & $\mathrm{~d}$ \\
\hline$(1-+9-+4-\mathrm{MP})$ & $11,12,14,15$ & 1.5 & High & $>1.2$ & $\mathrm{~g}$ \\
\hline
\end{tabular}




\section{${ }^{13}$ C analysis}

Using a separate approach, we examined soil organic matter in which Zea mays had been cultivated in two fields during 5 and 23 years (Table 2, Figure 4). After 23 years of maize cultivation, the isotope value of bulk soil organic carbon has increased by $+6 \%$, giving evidence for the input of maize-derived $\mathrm{C}$ into soil organic components. The contribution of maize-derived $\mathrm{C}$ within each soil component can be calculated using the following equation (Lichtfouse, 1995, 1997) :

$$
M=100 .\left(\delta-\delta_{0}\right) /\left(\delta_{m}-\delta_{0}\right)
$$

where $\mathrm{M}$ is the percentage of maize-derived $\mathrm{C}$ of the soil organic component, $\delta$ is the isotope value of this component at any time of maize cultivation, $\delta_{0}$ is the isotope value of this component before maize cultivation and $\delta_{m}$ is the isotope value of this component in maize. Thus, for bulk soil carbon, $M$ reaches $42 \%$ after 23 years of cultivation $\left(\delta_{\mathrm{m}}=-12.51 \%\right)$. This significant input of maize $\mathrm{C}$ into soil organic substances contrasts sharply with the absence of significant isotope variation of PAH fractions observed in the two fields. Such a finding clearly shows that most of the soil PAHs were not labelled by maize $\mathrm{C}$, and are therefore not biological products from plant, soil biomass and their humification products. An autotrophic contribution, e.g. from algae growing sporadically on the soil surface after rains, can be excluded because these organisms grow not only on atmospheric $\mathrm{CO}_{2}$ but also on soil $\mathrm{CO}_{2}$ which should be progressively labelled with ${ }^{13} \mathrm{C}$-enriched $\mathrm{C}$ from maize decomposition products. Moreover, the $\delta^{13} \mathrm{C}$ value of $\mathrm{PAH}$ fractions, $\sim-27 \%$, is not in agreement with a derivation from aromatized plant triterpenes. Indeed, given the $\delta^{13} \mathrm{C}$ value of $\sim-36.5 \%$ o of $\mathrm{C}_{27-33} n$-alkanes from wheat growing these fields (Lichtfouse et al., 1995b), one can roughly estimate a value of $-35.0 \%$ for associated triterpenoids on biosynthetic grounds, as discussed by Hayes (1993). Further aromatization of those substances during humification processes is not expected to give notable isotopic changes (Freeman et al., 1994).

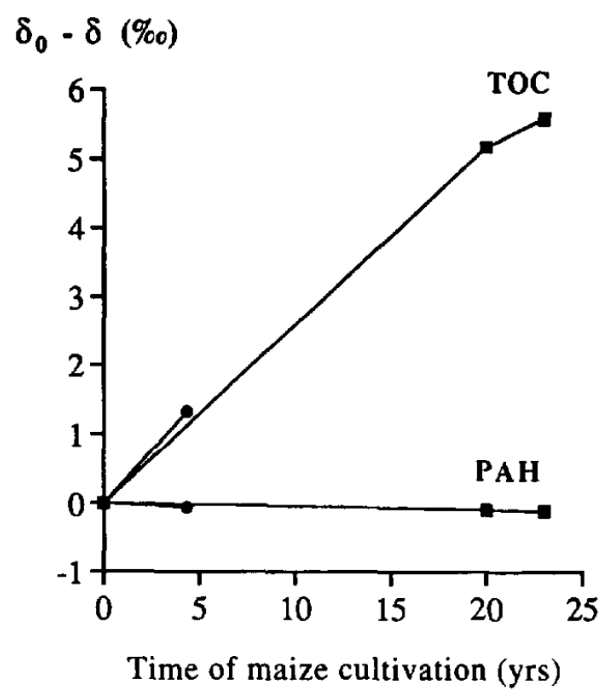

Figure 4. Isotope variations of total organic carbon (TOC) and aromatic fractions (PAH) from soils planted with maize at fields of La Minière (circles) and Boigneville (squares). TOC is strongly labeled by ${ }^{13} \mathrm{C}$-enriched $\mathrm{C}$ from Zea mays, whereas aromatic hydrocarbons do not show any isotope variation. $\delta_{0}$ refers to soils planted with $\mathrm{C}_{3}$ plants. $\delta$ refers to soils planted with Zea mays at one crop per year. 


\section{${ }^{14} \mathrm{C}$ analysis}

We dated one aromatic fraction by accelerator mass spectrometry, and found a value of $9820 \pm 70$ years BP with a fraction Modern (fM) of less than 29\% (see discussion by Lichtfouse and Eglinton, 1995). The average age of crop soil PAH is actually older than 9820 years because the convention for reporting $\mathrm{fM}$ is based on 1950 as $100 \%$ modern and does not take into account the large input of ${ }^{14} \mathrm{C}$ from bomb testing after 1950. This age really is in full agreement with the ancient origin of soil PAH. Two main sources can therefore be suggested based on our different approaches : first, a major input of pyrolytic products from combustion of fossil fuels. Nonetheless, a minor contribution from products of burning vegetation cannot be ruled out. Second, a minor contribution of (uncombusted) fossil fuels.

Derivation of PAHs from the initial soil rock is possible but very unlikely because 1) initial PAH would have been rapidly removed by extensive water washing, oxidation and biodegradation during cropping practices (Campbell, 1978, Anderson and Coleman, 1985, Arrouays and Pelissier, 1994), and 2) the constant concentration of soil PAHs during cultivation calls for a regular input, e.g. from aerosols and tractor exhausts. In this respect, it has been shown that terrestrial plants could be a notable sink of atmospheric particles and associated PAHs by adsorption on cuticular waxes (Smith, 1977, Simonich and Hites, 1994). Such a process should therefore rapidly introduce airborne particles into our soils, given the high turnover of plants by cropping practices. Alternatively, a regular, upward migration of trace amounts of fossil fuels from deeper formations is possible because the soils studied are situated on the Paris Basin, which is well-known for its petroleum production (Tissot et al., 1971, Lichtfouse et al., 1994).

Whatever the precise origin of soil PAHs, our approach using molecular and isotope information has clearly disclosed that soil PAHs are ancient and must represent a major, allochtonous contribution of pyrolytic products derived most likely from airborne particulates. It should also be noted that the absence of isotope variation of a component in a system subjected to isotope changes (in this case the shift from $\mathrm{C}_{3}$ to $\mathrm{C}_{4}$ vegetation) can give useful insights on its origin. Moreover, molecular maturity parameters, that have been developed by organic geochemists in the last 30 years to study recent and ancient sediments, are promising tools to track the fate of fossil fuels in the modern environment.

Acknowledgements- We thank Dr. James Bauer, College of William and Mary, for assistance with the radiocarbon measurements, and we thank Dr. Michaele Kashgarian, LLNL, for access to AMS facility. Drs. R. Kagi and M. Jones have provided helpful comments in reviewing this manuscript. This work was supported by the Institut National de la Recherche Agronomique (E. L.) and by an NSF grant (to T.I.E.) OCE9415568. 
REFERENCES

Anderson D. W. and Coleman D. C. (1985) The dynamics of organic matter in grassland soils. J. Soil Water Cons. 40, 211-216.

Arrouays D. and Pelissier P. (1994) Changes in carbon storage in temperate humic loamy soils after forest clearing and continuous corn cropping in France. Plant and Soil 160, 215-223.

Campbell C. A. (1978) Soil organic carbon, nitrogen and fertility. In Soil Organic Matter (Edited by Schnitzer M. and Khan S. U.) pp 173-271.

Currie L. A., Sheffield A.E., Riederer G. E. and Gordon G. E. (1994) Improved atmospheric understanding through explorating data analysis and complementary modeling : the urban K-Pb-C system. Atmos. Env. 28, 1359-1369.

Dastillung M. and Albrecht P. (1976) Molecular test for oil pollution in surface sediments. Marine Poll. Bull. 7, 13-15.

Douglas A. G. and Mair B. J. (1965) Sulfur : role in genesis of petroleum. Science 147, 499-501.

Freeman K. H., Boreham C. J., Summons R. E. and Hayes J. M. (1994) The effect of aromatization on the isotopic compositions of hydrocarbons during early diagenesis. Org. Geochem. 21, 1037-1049.

Garrigues P., Budzinski H., Manitz M. P. and Wise S. A. (1995) Pyrolytic and petrogenic inputs in recent sediments : a definitive signature through phenanthrene

and chrysene compound distribution. Polyc. Arom. Comp. 7, 275-284.

Garrigues P., De Sury R., Angelin M. L., Bellocq J., Oudin J. L. and Ewald M. (1988) Relation of the methylated aromatic hydrocarbon distribution pattern to the maturity of organic matter in ancient sediments from the Mahakam delta. Geochim. Cosmochim. Acta 52, 375-384.

Garrigues P., Narbonne J. F., Lafaurie M., Ribera D., Lemaire P., Raoux C., Michel X., Salaun J. P., Monod J. L. and Romeo M. (1993) Banking of environmental samples for short-term biochemical and chemical monitoring of organic

contamination in coastal marine sediments : the GICBEM experience (19861990). Sci. Tot. Environ. 139/140, 225-236.

Hayes J. M. (1993) Factors controlling ${ }^{13} \mathrm{C}$ contents of sedimentary organic compounds : principle and evidence. Marine Geol. 113, 111-125.

Hites R. A. and Biemann K. (1972) Water pollution : organic compounds in the Charles River, Boston. Science 178, 158-160.

Laflamme R. E. and Hites R. A. (1978) The global distribution of polycyclic aromatic hydrocarbons in recent sediments. Geochim. Cosmochim. Acta 42, 289-303.

Laflamme R. E. and Hites R. A. (1979) Tetra- and pentacyclic, naturally-occurring, aromatic hydrocarbons in recent sediments. Geochim. Cosmochim. Acta 43, 16871691.

Lichtfouse É. (1995) ${ }^{13} \mathrm{C}$ labelling of soil $n$-hentriacontane $\left(\mathrm{C}_{31}\right)$ by maize cultivation. Tetrahedron Lett. 36, 529-530.

Lichtfouse É. (1997) Heterogeneous turnover of molecular organic substances from crop soils as revealed by ${ }^{13} \mathrm{C}$ labeling at natural abundance with Zea mays. Naturwissenschaft. In press.

Lichtfouse É. and Albrecht P. (1994) Synthesis of triaromatic steroid hydrocarbons methylated at position 2, 3 or 6 : molecular fossils of yet unknown biological origin. Tetrahedron 50, 1731-1744.

Lichtfouse É., Albrecht P., Behar F. and Hayes J. M. (1994) A molecular and isotopic study of the organic matter from the Paris basin, France. Geochim. Cosmochim. Acta 58, 209-221. 
Lichtfouse É. and Budzinski H. (1995) ${ }^{13} \mathrm{C}$ analysis of molecular organic substances, a novel breakthrough in analytical sciences. Analusis 23, 364-369.

Lichtfouse E. and Eglinton T. I. (1995) ${ }^{13} \mathrm{C}$ and ${ }^{14} \mathrm{C}$ evidence of pollution of a soil by fossil fuel and reconstruction of the composition of the pollutant. Org. Geochem. 23, 969-973.

Lichtfouse É., Berthier G., Houot S., Barriuso E., Bergheaud V. and Vallaeys T. (1995a) Stable carbon isotope evidence for the microbial origin of $\mathrm{C}_{14}-\mathrm{C}_{18}{ }^{n-}$

alkanoic acids in soils. Org. Geochem. 23, 849-852.

Lichtfouse É., Dou S., Girardin C., Grably M., Balesdent J., Behar F. and Vandenbroucke M. (1995b) Unexpected ${ }^{13}$ C-enrichment of organic components

from wheat crop soils : evidence for the in situ origin of soil organic matter. Org.

Geochem. 23, 865-868.

Lipiatou E. and Saliot A. (1991) Fluxes and transport of anthropogenic and natural polycyclic aromatic hydrocarbons in the western Mediterranean Sea. Marine Chem. 32, 51-71.

Lunde G. and Bjorseth A. (1977) Polycyclic aromatic hydrocarbons in long-range transported aerosols. Nature 268, 518-519.

Mackenzie A. S., Brassell S. C., Eglinton G. and Maxwell J. R. (1982) Chemical fossils : the geological fate of steroids. Science 217, 491-504.

Mackenzie A. S., Patience R. L., Maxwell J. R., Vandenbroucke M. and Durand B. (1980) Molecular parameters of maturation in the Toarcian shales, Paris Basin, France. I. Changes in the configurations of acyclic isoprenoid alkanes, steranes and triterpanes. Geochim. Cosmochim. Acta 44, 1709-1721.

McCarthy R. D. and Duthie A. H. (1962) A rapid quantitative method for the separation of free fatty acids from other lipids. J. Lipid Res. 3, 117-119.

McElroy A., Farrington J. and Teal J. (1989) Bioavailability of PAH in the aquatic environment. In Metabolism of Polycyclic Aromatic Hydrocarbons in the aquatic Environment (Edited by V. Varanasi) pp 1-40. CRC Press.

Ourisson G., Albrecht P. and Rohmer M. (1979) The hopanoids. Palaeochemistry and biochemistry of a group of natural products. Pure \& Appl. Chem. 51, 709-729.

Pahlman R. and Pelkoner O. (1987) Mutagenicity studies of different polycyclic aromatic hydrocarbons : the significance of enzymatic factors and molecular structure. Carcinogenesis 8, 773-778.

Peters K. E. and Moldowan J. M. (1993) The Biomarker Guide. Interpreting Molecular Fossils in Petroleum and Ancient Sediments, 363 pp., Prentice Hall, Englewood Cliffs.

Radke M. (1987) Organic geochemistry of aromatic hydrocarbons. In Advances in Petroleum Geochemistry (Edited by Brooks J. and Welte D. H.) pp 141-206. Academic press, London.

Radke M., Garrigues P. and Willsch H. (1990) Methylated dicyclic and tricyclic hydrocarbons in crude oils from the Handil field, Indonesia. Org. Geochem. 15, 1734.

Radke M., Rullkötter J. and Vriend S. P. (1994) Distribution of naphthalenes in crude oils from the Java Sea : source and maturation effects. Geochim. Cosmochim. Acta 58, 3675-3689.

Radke M., Welte D. H. and Willsch H. (1986) Maturity parameters based on aromatic hydrocarbons : influence of the organic matter type. Org. Geochem. 10, 51-63.

Radke M., Willsch H., Leythaeuser D. and Teichmüller M. (1982) Aromatic components of coal : relation of distribution pattern to rank. Geochim. Cosmochim. Acta 46, 1831-1848. 
Radke M., Willsch H. and Welte D. (1984) Class separation of aromatic compounds in rock extracts and fossil fuels by liquid chromatography. Anal. Chem. 56, 2538-2546.

Seifert W. K. and Moldowan J. M. (1978) Applications of steranes, terpanes and monoaromatics to the maturation, migration and source of crude oils. Geochim. Cosmochim. Acta 42, 77-95.

Sicre M. A., Marty J. C., Saliot A., Aparicio X., Grimalt J. and Albaiges J. (1987) Aliphatic and aromatic hydrocarbons in different sized aerosols over the

mediterranean sea : occurrence and origin. Atmosph. Environ. 21, 2247-2259.

Simoneit B. R. T., Brault M. and Saliot A. (1990) Hydrocarbons associated with hydrothermal minerals, vent waters and talus on the East Pacific Rise and Mid-

Atlantic Ridge. Appl. Geochem. 5, 115-124.

Simonich S. L. and Hites R. A. (1994) Importance of vegetation in removing polycyclic aromatic hydrocarbons from the atmosphere. Nature 370, 49-51.

Simonich S. L. and Hites R. A. (1994) Vegetation-atmosphere partitioning of

polycyclic aromatic hydrocarbons. Environ. Sci. Technol. 28, 939-943.

Smith W. H. (1977) Removal of atmospheric particulates by urban vegetation : implications for human and vegetative health. Yale J. Biol. Med. 50, 185-197.

Tissot B. P. and Welte D. H. (1984) Petroleum Formation and Occurrence. Springer, Berlin.

Tissot B., Califet-Debyser Y., Deroo G. and Oudin J. L. (1971) Origin and evolution of hydrocarbons in Early Toarcian Shales, Paris Basin, France. Amer. Assoc. Petrol. Geol. Bull. 55, 2177-2193.

Trendel J. M., Lohmann F., Kintzinger J. P., Albrecht P., Chiaroni A., Riche C., Cesario M., Guilhem J. and Pascard C. (1989) Identification of Des- $A$-triterpenoid hydrocarbons occurring in surface sediments. Tetrahedron 45, 4457-4470.

Van Dorsselaer A., Ensminger A., Spyckerelle C., Dastillung M., Siesking O., Arpino P., Albrecht P., Ourisson G., Brooks P. W., Gaskell S. J., Kimble B. J., Philp R.

P., Maxwell J. R. and Eglinton G. (1974) Degraded and extended hopane derivatives $\left(\mathrm{C}_{27}\right.$ to $\left.\mathrm{C}_{35}\right)$ as ubiquitous geochemical markers. Tetrahedron Lett. 14, 1349-1352.

Windsor J. G. and Hites R. A. (1979) Polycyclic aromatic hydrocarbons in gulf of Maine sediments and Nova Scotia soils. Geochim. Cosmochim. Acta 43, 27-33.

Wise S., Hilpert L., Rebbert R., Sander R., Schantz M., Chesler S. and May W. (1988)

Standard reference material for the determination of polycyclic aromatic

hydrocarbons. $\quad$ Fresenius Z. Anal. Chem. 332, 576-582.

White K. (1986) An overview of imunotoxicology and carcinogenic polycyclic aromatic hydrocarbons. Environ. Carcino. Revs. (J. Environ. Sci. Health) C4(2), 163-202.

Youngblood W. W. and Blumer M. (1975) Polycyclic aromatic hydrocarbons in the environment : homologous series in soils and recent marine sediments. Geochim. Cosmochim. Acta 39, 1303-1314. 